\title{
UNEARTHING CATALAN MUSICAL HERITAGE: THE IFMuC PROJECT
}

\author{
Aurèlia Pessarrodona and Josep Maria Gregori
}

\author{
In memoriam Maria Dolors Millet $i$ Loras (1937-2017), librarian of the Institut de \\ Documentació i d'Investigació Musicologiques "Josep Ricart i Matas" and Francesc Bonastre \\ Bertran (1944-2017), founder and director of this centre and Professor of Musicology \\ at the Universitat Autònoma de Barcelona
}

\section{Introduction}

Who knows anything about our art of music, about its character and about its tendencies? Who cares about scrutinising where we come from in order to know where we are going? Who deems it necessary to know something more about the text of an art, whatever we want, if the spirit which fecundates it is absolutely unknown? ${ }^{1}$

The above quote is the rhetorical manner in which Felip Pedrell (1841-1922), considered the "father" of modern Spanish musicology, laid out the need to rescue musical heritage at the beginning of the 'Proemi' in his Catàlech de la Biblioteca Musical de la Diputació de Barcelona (1908). This book was the first attempt, not only in Catalonia but also in all of Spain, at publishing a systematic catalogue of a public music archive, specifically the music collection of the bibliophile Joan Carreras Dagas (1828-1900). The collection was purchased by the Diputació de Barcelona to become the main part of its music library, now the Music Section of the National Library of Catalonia.

\footnotetext{
Aurèlia Pessarrodona i Pérez is a musicologist and soprano. She holds the BA in Humanities (Universitat Pompeu Fabra, 2000), a Ph.D. in Musicology (Universitat Autònoma de Barcelona, 2010), and a Higher Diploma in Lyric Singing and Vocal Didactics (Bologna, Italy, 2015). Her main area of research has been musical theatre in Spain during the second half of the eighteenth century in such genres as the tonadilla and dance music-this latter field together with the choreologist María José Ruiz Mayordomo. She currently has a postdoctoral fellowship ('Juan de la Cierva Incorporación') at the Department of Art and Musicology at the Universitat Autònoma de Barcelona, where she collaborates with the IFMuC project as a researcher and lecturer for the 'Musical Heritage' project included in the degree in Musicology.

Josep Maria Gregori i Cifré is a musicologist and countertenor. He was trained as a musicologist at the Universitat Autònoma de Barcelona, obtaining a BA degree in 1977 with a dissertation on the composer Joan Crisòstom Ripollès (1678-1746), and a Ph.D. with his thesis La música del Renaixement a la catedral de Barcelona, 1450-1582. Since 1978, he has been teaching at the Universitat Autònoma de Barcelona, where he holds the Chair of Musical Heritage. He is the recipient of several musicology research awards, including the Higini Anglès Prize (1977), Fundació Güell (1982), Emili Pujol (1991), Ernest Lluch Foundation (2008), E. Lluch Ciutat d'Olot grant (2010), and J. Mercader (2014). His musicological research embraces historical and performing aspects from the fifteenth to eighteenth centuries and topics about musical philosophy and aesthetics, with the publication of the essay, Mvsica Caelestis. Reflexions sobre Música i Simbol (Arola-URV, 2012). In 20012002, he came to the Universitat Autònoma de Barcelona in order to catalogue Catalan musical collections in the IFMuC project.

1. Felip Pedrell, Catàlech de la Biblioteca Musical de la Diputació de Barcelona (Vilanova i la Geltrú: Oliva, 1908), Vol. I, 3 (original in Catalan): “Qui sab quelcom de nostra art de música, de son caracter y de les seves tendencies? A qui li importa escorcollar d'ont venim pera saber ont anem? Qui creu necessari saber quelcom més de la lletra d'una art, sí a la que vulga, si’s desconeix per complert l'esperit que la feconda?”
} 
Pedrell was entirely convinced of the necessity to know the music of a nation's past in order to enhance its modern-day musical production. This ideal, linked with the contemporaneous "Renegationism"-of interest for remedying Spain's decline, especially after the loss of its colonies in 1898-insists on the importance of preserving one's own cultural heritage, which coincides with further initiatives, for example, that reflected on the Web site of the General Direction of Cultural Heritage of the Autonomous Government of Catalonia, created in 1980: "Catalan society values and feels rooted in the heritage that conforms its cultural and historical legacy and its collective memory".

Nevertheless, since Pedrell no scholar has attempted significant initiatives regarding a project designed to systematically document the musical richness conserved in Catalan archives. Catalonia was therefore one of the few European regions still unaware of the richness of its musical heritage in terms of the repertory of compositions by its chapel masters, organists, and musicians, which are conserved but forgotten in numerous, mainly ecclesiastic, archives, and has managed to survive the numerous wars that have blighted Spain in the past 500 years.

For this reason, at the beginning of the 2001-2002 academic year in the Department of Art and Musicology of the Universitat Autònoma de Barcelona (Autonomous University of Barcelona [UAB]), a group of researchers and students led by Professor Josep Maria Gregori i Cifré initiated a new line of research with the immediate priority of working to recover the collections of manuscripts that constitute the musical heritage of Catalonia. This initiative has continued to the present, becoming the IFMuC Project, an acronym of the Inventaris dels Fons Musicals de Catalunya (Inventories of the Catalan Musical Collections), and has launched the production and publication, in printed form, of inventories and the creation of a digital database. Under the direction of Josep Maria Gregori, other researchers in the group-all from the same University-have been professors Jordi Rifé (in the first period), Bernat Cabré and Aurèlia Pessarrodona, and the graduate student Carles Badal, with major input from the invaluable efforts and support of the students pursuing a degree in musicology.

From a systematic point of view, the IFMuC's mission is guided by the desire to uncover and share the results of a promising project, one that is rich for researchers, performers of ancient and classical music in general, and pedagogues. The project also benefits society as a whole, which now more than ever is seeking to rediscover its roots and, with them, its musical past.

This article presents the IFMuC Project in an international forum in order to demonstrate its value beyond Catalonia. It will be a useful source for researchers and musicians outside of Catalonia, not only to make Catalan musical heritage known, but also as a tool for more in-depth study of the movement of music and musicians across countries. The IFMuC Project can also suggest ways to develop-hopefully collaboratively-more databases of music collections in other countries and regions.

2. http://cultura.gencat.cat/ca/departament/estructura_i_adreces/organismes/dgpc/direccio_general /historia/ (accessed 18 August 2017): "La societat catalana valora i se sent arrelada al patrimoni que conforma la seva herència cultural i històrica, la seva memòria col-lectiva”. 


\section{Background: The IFMuC Project in the Context of Previous Initiatives to Recover Catalan Musical Heritage}

At least three previous initiatives to recover and disseminate Catalan musical heritage have converged, more or less directly, in the IFMuC Project: the Centre de Documentació Musical (Center of Musical Research) at the UAB, a research group formed by musicologists Maria Ester-Sala and Josep Maria Vilar, and RISM-Spain.

\section{Inside the (same) University: The Centre de Documentacio Musical and the Institut Universitari de Documentació i d'Investigació Musicologiques "Josep Ricarti Matas"}

With the passage of the Spanish General Education Law in 1970, courses in the history of music began to be officially offered in universities for the first time, albeit as one subject included in the Bachelor's Degree in the History of Art. In 1973, this inclusion helped to develop a musicology curriculum at the recently created UAB (founded in 1968), specifically in its Department of Art. This project was led by Professor Francesc Bonastre and Antonio Martín Moreno, then a predoctoral scholarship recipient at the Consejo Superior de Investigaciones Científicas (Superior Council of Scientific Research, or CSIC), in Barcelona. This was the first time a Spanish university had established a curriculum in musicology ${ }^{3}$.

Also in 1973, within this context, Bonastre founded the Centre de Documentació Musical at the UAB, which operated until 1979 in collaboration with Professor Antonio Martín Moreno and the students in the UAB Music Department. This team created an inventory of the collections of music manuscripts in Tarragona Cathedral, the churches of Sant Joan de les Abadesses, Santa Pau dels Arcs, Santa Maria de la Geltrú, but only a quarter of those in Sant Esteve d'Olot. From 1980 to 2016, the work continued at the Institut Universitari de Documentació i Investigació Musicològiques 'Josep Ricart i Matas' (Graduate Institute of Musicological Documentation and Research 'Josep Ricart i Matas' $)^{4}$. This involved microfilming the collection in Tarragona Cathedral (1980-1981), the inventory and microfilming of the collection in Sant Pere de Canet de Mar (19811984), and an initial inventory of the collection in Santa Maria de Vilafranca del Penedès (1986). All this material is now preserved in the Ricart i Matas Collection in the Reial Acadèmia Catalana de Belles Arts de Sant Jordi (Catalonian Royal Academy of Fine Arts of Saint George).

These experiences sparked the enthusiasm of young musicologists-such as Josep Maria Gregori-to rescue the Catalan musical heritage, and lay down basic guidelines for the IFMuC Project.

\section{Outside Academia: Maria Ester-Sala and Josep Maria Vilar (1984-1991)}

Another interesting initiative was conducted outside of academia, with a team formed by the musicologists Maria Ester-Sala (1946-1994) and Josep Maria Vilar-both educated

3. For a more detailed explanation about the creation of the Degree in Musicology at the UAB, see Antonio Martín Moreno, "La musicologia catalana, des de Pedrell a l'actualitat", in Història Crítica de la Música Catalana, ed. Francesc Bonastre and Francesc Cortès ([Bellaterra]: Universitat Autònoma de Barcelona, 2009), 515-572.

4. See Josep Maria Gregori i Cifré, "La catalogació dels arxius musicals de Catalunya, una de les línies de recerca de l'IDIM de la UAB”, in I Congrés de Música a Catalunya, ed. Consell Català de la Música (Barcelona: Consell Català de la Música, 1994), 863-865. 
at the UAB-who conducted an extended study of the musical collections preserved in Catalonia. This project began in 1984 when Josep Maria Vilar catalogued the collection of music manuscripts in Manresa Cathedral for his bachelor's degree thesis, directed by Francesc Bonastre, and defended at the UAB in July of that year ${ }^{5}$. As such, for almost four years (1984-1987), both musicologists conducted extensive fieldwork throughout Catalonia in search of musical archives. The journal Anuario Musical published the first results of their work, which provided a list of more than 900 authors found in the thirteen music collections they visited ${ }^{6}$.

In 1988, they began to publish in the Revista Musical Catalana-the most important Catalan music magazine-brief monthly reports of Catalan music collections, with an approximate estimate of the number of manuscripts and printed sources, periods covered, and the main authors and genres. By 1992, after several years of work, they produced thirty-two reports on fifty-one music archives. In 1989 and 1991, they also published their research in the Anuario Musical, providing information on more than 1,800 authors in sixty-one archives with music collections.

This project culminated in 1992 with the publication of the article "Els fons musicals a Catalunya: un patrimoni a revalorar" (Musical Collections in Catalonia: A Heritage of Outstanding Value) ${ }^{7}$, a summary of eight years of intense research, which covered 171 archives, 111 of which had music collections or some music material. Most importantly, the article included proposals to launch a coordinated process for unearthing Catalan musical heritage.

Although these musicologists did not catalogue the collections, their desire to be comprehensive-encompassing the broadest number of archives and collections-and to disseminate information on them has had a strong influence on the IFMuC Project.

\section{An International Perspective: RISM- España (1991)}

After the end of the Spanish Civil War in 1939, the Instituto Español de Musicología (Spanish Institute of Musicology)—now the Department of Musicology at the Milà i Fontanals Institution-was founded in Barcelona in 1943 as one section of the CSIC. Thanks to the work of its first director, Higini Anglès (1888-1969), among others, this institution has become an unquestioned leader in its field.

One of its most important milestones was the creation of the Redacción Central del RISM-España (Central Office of RISM-Spain) ${ }^{8}$, the focus of RISM activity in Spain-the first of outside of the Zentralredaktion in Frankfurt-which began its activity in 1991 thanks to the then director, José V. González Valle. Since then, this institute has catalogued Spanish and Latin American music collections, as well as those of the Archive of

5. This monumental catalogue, not yet published, offers a total of 1,765 works and was produced in accordance with the methodological rules of the Institut Universitari de Documentació i d'Investigació Musicològiques 'Josep Ricart i Matas'.

6. Maria Ester Sala and Josep Maria Vilar, "Una aproximació als fons de manuscrits musicals a Catalunya”, Anuario Musical 42 (1987): 229-243.

7. In Lligall, Revista Catalana d'Arxivística, 5 (1992): 123-146.

8. For more information about the creation of this workgroup, see Antonio Ezquerro, "RISM-España (Répértoire International des Sources Musicales): importancia del proyecto y alcance de sus actividades. La redacción central de Barcelona”, Anuario Musical 49 (1994): 273-277; id., "Cataloguing Musical Sources in Spain: A RISM Perspective”, Fontes Artis Musicae 45, no. 1 (January-March 1998): 81-89; id., "Neue Herausforderungen im Umfeld des RISM-Projektes: Der Fall Spaniens”, Fontes Artis Musicae 56, no. 2 (April-June 2009): 201-206. 
the Crown of Aragon, the Archive of the Kingdom of Mallorca, and the archives of the cathedrals of Tortosa and of la Seu d'Urgell.

RISM, as is well known, is the largest global project that documents music sources, providing scholars and musicians alike with an extensive catalogue and comprehensive inventory. The IFMuC criteria are not exactly the same as those of RISM, but its digital cataloguing system is easily adaptable to the RISM format, facilitating the automatic integration of IFMuC records into the RISM database.

\section{The IFMuC Project: Recovering Musical Heritage with a Pedagogical Aim}

The UAB undertook a curriculum reform in musicological studies during the 19992000 academic year, resulting in a university degree called "History and Sciences of Music". This new degree was the perfect platform to develop a new line of research with the recovery of Catalan musical heritage as its main priority. The project realised the possibilities of the new "Spanish and Latin American Musical Heritage" subject, as conceived by Josep Maria Gregori i Cifré, which included a percentage of credit hours awarded to students that, under tutorial guidance, produced inventories of different music archives in Catalonia.

The pilot project, conducted by a group of eighteen students, was the cataloguing of the rich musical collection of Bernat Calbó Puig (1819-1880), preserved in the Provincial Archive of the Capuchins of Catalonia. This first experience was so successful that in the second semester some students presented proposals to do similar onsite work in archives near their places of residence. This exponentially increased the activity of the pilot project in Catalonia because of the interest of the students themselves. Since then, the main procedure has been to catalogue a major archive as a major focus and, simultaneously, many smaller archives across the country, always conducted by students of "Spanish and Latin American Musical Heritage”, or those on work experience agreements.

This project has continued successfully up to now, as part of the "Musical Heritage" subject included in the bachelor's degree in musicology, which was implemented via the European Higher Education Area at the UAB in the 2008-2009 academic year. In fact, this fieldwork is a highly enriching experience for the students, because they have the opportunity to make direct contact with original music sources, posing multiple questions and reflections about the creation process and interpretation of this repertory, which can also raise interest in musicological research in new degree projects ${ }^{9}$.

9. For example, Neus Cabot, "La música a Santa Maria de Mataró (1830-1944). Els fons de Joan Fargas i Lluís Viada”, research dissertation for the Master's Degree in Advanced Studies in Musicology, UAB, 26 January 2010; Olga Niubó, 'La música a Tàrrega a finals del s. XIX i inicis del s. XX. El fons musical Ramon Florensa de l'Arxiu Comarcal de l'Urgell”, thesis for the Master's Degree in Musicology, UAB, 13 September 2010; Sandra Coronel, "La música a la basílica del Sant Esperit de Terrassa al segle XIX: Marc Biosca Barba", thesis for the Master's Degree in Musicology, UAB, 13 September 2010; Maria del Mar Correu Perales, "Els goigs de la Mare de Déu de la Misericòrdia de Ramon Clausell", 7 September 2010; Anna Artigas, "Llibres corals del monestir de Sant Pere de les Puelles: descripció de sis volums antifoner, miscellània de misses, seqüències i altres formes”, thesis for the Master's Degree in Archival Science, UAB - Escola Superior d'Arxivística i Gestió Documental de la UAB, September 2013; Elena Salgado, "La capella de música de Castelló d’Empúries. Catalogació del seu fons musical”, thesis for the Master's Degree in Musicology, UAB, September 2013; Carles Badal, "Pau Llinàs, mestre de capella de Santa Maria del Pi (1711-1749). Estudi biogràfic, catalogació i transcripció de l'obra complete”, thesis for the Master's Degree in Musicology, 31 July 2016. All of these dissertations were directed by Josep Maria Gregori i Cifré, some of which were the origin of the subsequent volume published in the Inventaris dels Fons Musicals de Catalunya series. 
From 2001 to 2016, thanks to this extensive work, the IFMuC Project has registered almost 300 collections of manuscripts containing unknown works by Catalan composers. This only represents a small percentage of the musical richness that is stored in the historical collections of our cathedrals, basilicas, and parish churches. Of the collections housed in public, ecclesiastic, and private archives, seventeen have been catalogued, with an index of approximately 1,000 composers and 10,358 recorded works, including manuscripts and printed materials (see table 1); a considerable number of music collections are still in the cataloguing process (see Appendix). An important part of this work has been made possible thanks to four research and development projects financed by the Spanish Ministry of Economy and Competitiveness (those of 2003-2006; 2007-2010; 2010-2014, and 2015-2018) and, from 2006 to 2010, with the support of the Catalan Government's General Sub-Directorate for Heritage.

\section{Methodology}

\section{Generalities}

As musicologists, not trained as documentalists or archivists, we do not claim to produce exhaustive and detailed descriptive catalogues, but rather inventories that are flexible and easy to prepare, computerise, and publish in paper and digital form, for presentation in an easy and user-friendly manner.

The process ${ }^{10}$ consists of the following main phases:

1) An initial visual inspection to assess the state of the collection.

2) A first arrangement with a provisional pre-inventory, in order to get a real idea of the extent of the collection.

3) Record entry process, detailed below.

4) Identification of the disparate fragments and definitive arrangement, according to alphabetical criteria of author, generic title, or literary incipit.

5) Photographing of musical incipits.

6) Preparation and edition of the inventory for publication.

In order to make this work known to other researchers, a mid-term initiative within the IFMuC Project is the publication of a handbook for the cataloguing of music collections in accordance with the rules of the project, the result of all these years of experience. The authors will be Josep Maria Gregori and Marta Grassot, director of the Centre de Documentació de l'Orfeó Catalá (Centre of Documentation of the Orfeó Català [CEDOC]), one

10. For a more detailed explanation of this process, see Josep Maria Gregori i Cifré and Jordi Rifé i Santaló, "Els fons musicals de Catalunya: estat de la quiestió”, Recerca Musicològica 16 (2006): 219-239, at 226-233. The process described therein was made faster thanks to technological advances. Another bibliography that details the IFMuC Project is Josep Maria Gregori, "El inventario de los fondos musicales eclesiásticos de Catalunya, un proyecto en marcha desde la Universitat Autònoma de Barcelona", Memoria Ecclesiae 31 (2008): 483-497; "Els Inventaris dels Fons Musicals de Catalunya, el projecte de la UAB per a la recuperació del patrimoni musical”, in $2 n$ Congrés Internacional de Música (Barcelona: Consell Català de la Música, 2013), 621-625; "Fondos Musicales en Catalunya: el proyecto IFMuC de la Universitat Autònoma de Barcelona para la recuperación del patrimonio musical catalán”, in Allegro cum laude. Estudios musicológicos en homenaje a Emilio Casares, ed. Maria Nagore and Víctor Sánchez (Madrid: Instituto Complutense de Ciencias Musicales, 2014): 127-134; "Catalonia Project Report”, Early Music 43 (2015): 367-368; and "El Cens IFMuC dels fons musicals de Catalunya”, Lligall 38 (2016): 134-168. 
Table 1. Inventories Completed by the IFMuC Project.

\begin{tabular}{|c|c|c|c|c|c|}
\hline Collection and Archive (acronym) & $\begin{array}{l}\text { Authored } \\
\text { Works }\end{array}$ & $\begin{array}{l}\text { Anonymous } \\
\text { Works }\end{array}$ & $\begin{array}{l}\text { Printed } \\
\text { Scores }\end{array}$ & $\begin{array}{l}\text { Choral } \\
\text { Books }\end{array}$ & $\begin{array}{l}\text { Period } \\
\text { (centuries) }\end{array}$ \\
\hline $\begin{array}{l}\text { Cathedral Basilica of the Sant Esperit of } \\
\text { Terrassa (TerC) }\end{array}$ & 672 & 291 & 9 & 16 & 18th-20th \\
\hline $\begin{array}{l}\text { Parish Church of Sant Pere i Sant Pau of } \\
\text { Canet de Mar (CMar) }\end{array}$ & 1,196 & 923 & & & 17th-19th \\
\hline $\begin{array}{l}\text { Vicenç Bou Collection, in the } \\
\text { Mediterranean Museum of Torroella de } \\
\text { Montgri (TomB) }\end{array}$ & 480 & 4 & & & 19th-20th \\
\hline $\begin{array}{l}\text { Josep Pi Collection, in the Mediterranean } \\
\text { Museum of Torroella de Montgri (TomP) }\end{array}$ & 476 & 4 & 5 & & 19th-20th \\
\hline $\begin{array}{l}\text { Pere Rigau Collection, in the Mediterranean } \\
\text { Museum of Torroella de Montgri (TomR) }\end{array}$ & 475 & & 5 & & 19th-20th \\
\hline $\begin{array}{l}\text { The collection of the Musical Chapel of the } \\
\text { Museum-Archive of Santa Maria de Mataro } \\
\text { (MatC) }\end{array}$ & 127 & 207 & & & 18th-20th \\
\hline $\begin{array}{l}\text { Joan Fargas i Heras Collection of the } \\
\text { Museum-Archive of Santa Maria de Mataró } \\
\text { (MatF) }\end{array}$ & 163 & 5 & 35 & & 19th-20th \\
\hline $\begin{array}{l}\text { Lluís Viada i Castellà Collection of the } \\
\text { Museum-Archive of Santa Maria de Mataró } \\
\text { (MatV) }\end{array}$ & 131 & 27 & 5 & & 19th-20th \\
\hline $\begin{array}{l}\text { Ramon Florensa Collection, from the parish } \\
\text { of Santa Maria d'Alba, preserved in the } \\
\text { Regional Archive of l'Urgell (TagF) }\end{array}$ & 208 & 172 & & & 18th-19th \\
\hline $\begin{array}{l}\text { Musical collection of the parish church of } \\
\text { Sant Esteve d'Olot (SEO), preserved in the } \\
\text { Regional Archive of la Garrotxa (ACGAX) }\end{array}$ & 1,359 & 409 & 468 & 23 & 18th-20th \\
\hline $\begin{array}{l}\text { Teodoro Echegoyen Collection (TEch), } \\
\text { preserved in the Regional Archive of la } \\
\text { Garrotxa (ACGAX) }\end{array}$ & 218 & 3 & 7 & & 19th-20th \\
\hline $\begin{array}{l}\text { Basilica of Santa Maria de Castelló } \\
\text { d'Empúries (CdE), preserved in the } \\
\text { Diocesan Archive of Girona (ADG) }\end{array}$ & 209 & 96 & 109 & & 19th-20th \\
\hline $\begin{array}{l}\text { Tarragona Cathedral (TarC), preserved in } \\
\text { the Historical Archdiocesan Archive of } \\
\text { Tarragona (AHAT) }\end{array}$ & 1,114 & 229 & 119 & 74 & 17th-20th \\
\hline $\begin{array}{l}\text { Basilica of Santa Maria d'Igualada (SMI), } \\
\text { preserved in the Regional Archive of } \\
\text { l'Anoia (ACAN) }\end{array}$ & 632 & 157 & 188 & 7 & 18th-20th \\
\hline $\begin{array}{l}\text { Artur Sitjà Collection (GrAS), preserved in } \\
\text { the Regional Archive of Vallès Oriental } \\
\text { (ACVO) }\end{array}$ & 24 & & 1 & & 19th-20th \\
\hline $\begin{array}{l}\text { Joan Vernet Collection (GrJV), preserved in } \\
\text { the Regional Archive of Vallès Oriental }\end{array}$ & 27 & & 83 & & 19th-20th \\
\hline $\begin{array}{l}\text { Salvador d'Horta Bofarull Collection } \\
\text { (SHB), preserved in the Episcopal Public } \\
\text { Library of the Seminary of Barcelona } \\
\text { (BPESB) }\end{array}$ & 27 & & 27 & & 19th-20th \\
\hline
\end{tabular}


of the earliest Catalan institutions with an interest in preserving and disseminating their own musical heritage ${ }^{11}$.

\section{The Record Entry Process}

The fields on the inventory card are defined according to the antiquarian system, with some specific ones for music information:

- Location area.

- Title and statement of responsibility area.

- Musical information area.

- Physical description area.

- Note area.

- Musical incipits: if the record entry process is done manually, these are handwritten on the back of each card.

In fact, over the years the record entry process, although originally done on paper cards, has been adapted to new technologies; for example, the features of some archives mean that this process can be done directly on a computer using File Maker software.

Indeed, the experience has shown us that each music collection has its own peculiarities, and for many reasons: being the historical deposit of an ecclesiastical institution-as in most cases-a private collection that groups together compositions by one author, or a miscellaneous collection resulting from a variety of contributions and donations. For this reason, we have established three description levels in accordance with the specificity of each collection and the willingness and dedication of the members of the group. The first level is the most complete and includes all fields on the card; the second level is focussed on information about the configuration and state of the collection and the physical description of each record; and in the third level the information is limited to what is most essential: location area (signatures), title and statement of responsibility area, incipits, and notes. These second and third levels enable the inventory of large collections to be completed in a reasonable amount of time, with the possibility of recording the remaining fields in the future.

This record entry process is the phase where students are most directly involved, because they file the cards. This task might be particularly difficult for them, but at the same time, it is a very rewarding experience. When students are faced for the first time with historical manuscripts, this is when they become aware of their own responsibility for their own historical music heritage, in some cases generating genuine interest in continuing this work beyond the academic curriculum.

The work done by the students is revised and corrected by supervisors. When all of the information is processed in the File Maker database, the identification of disparate fragments and anonymous works is relatively quick, for example, by comparing literary incipits with musical ones, or through other information, such as musicians, tonality, etc. Each record also includes a digital image of the musical incipits, which, after editing, are attached. These digital images, apart from accelerating the process, also make it possible to visualise the palaeographic features of the manuscript.

11. See, for example, Lluís Millet i Loras. "El llegat històric de l’Orfeó Català (1891-1936)”, Recerca Musicologica 14-15 (2004-2005): 139-153. 


\section{Dissemination}

Different strategies are employed in the dissemination process, including the publishing of printed copies of some series, articles in magasines and above all the creation of a Web site with a digital database.

\section{The 'Inventaris dels Fons Musicals de Catalunya' Series}

Between 2007 and 2016, the inventory of fourteen of the seventeen catalogued collections was published in print, the first through initial sponsorship by the Catalan Government's General Sub-Directorate for Heritage. The published volumes are:

1) Josep Maria Gregori. Fons de la catedral-basílica del Sant Esperit de Terrassa. Inventaris dels fons musicals de Catalunya; 1 (Barcelona: Departament de Cultura i Mitjans de Comunicació de la Generalitat de Catalunya, 2007 - Arxius i documents. Eines de recerca, 2): 566 pages.

2) Francesc Bonastre and Josep Maria Gregori, with the collaboration of Andreu Guinart. Fons de la Parròquia de Sant Pere $i$ Sant Pau de Canet de Mar. Inventaris dels Fons Musicals de Catalunya; 2/1 and 2/2 (Barcelona: Departament de Cultura i Mitjans de Comunicació de la Generalitat de Catalunya, 2009. - Arxius i documents. Eines de recerca, 5/1 - 5/2): 1,014 pages.

3) Marta Grassot. Fons V. Bou, J. Pi i P. Rigau i del Centre Cultural i de la Mediterrània Can Quintana de Torruella de Montgrí. Inventaris dels fons musicals de Catalunya; 3 (Barcelona: Departament de Cultura i Mitjans de Comunicació de la Generalitat de Catalunya, 2009. -Arxius i documents. Eines de recerca, 6): 439 pages.

4) Josep Maria Gregori and Neus Cabot. Fons del Museu-Arxiu de Santa Maria de Mataró. Inventaris dels fons musicals de Catalunya; 4 (Barcelona: UAB - Departament de Cultura i Mitjans de Comunicació de la Generalitat de Catalunya, 2010. - Arxius i documents. Eines de recerca, 7): 362 pages.

5) Olga Niubó. Fons Ramon Florensa de l'Arxiu Comarcal de l'Urgell. Inventaris dels fons musicals de Catalunya; 5 (Barcelona: UAB - Departament de Cultura i Mitjans de Comunicació de la Generalitat de Catalunya, 2011. - Arxius i documents. Eines de recerca, 8): 200 pages.

6) Josep Maria Gregori and Carme Monells. Fons de l'església parroquial de Sant Esteve d'Olot $i$ Fons Teodoro Echegoyen de l'ACGAX. Inventaris dels fons musicals de Catalunya; 6 (Barcelona: UAB, 2012): 1,218 pages.

7) Josep Maria Gregori and Elena Salgado. Fons de la basílica de Santa Maria de Castelló d'Empúries. Inventaris dels fons musicals de Catalunya; 7 (Barcelona: UAB, 2013): 221 pages.

8) Francesc Bonastre, Josep Maria and Montserrat Canela. Fons de Catedral de Tarragona. Inventaris dels fons musicals de Catalunya; 8 (Barcelona: UAB, 2015): 865 pages.

9) Josep Maria Gregori and Anna Romeu. Fons de la basílica de Santa Maria d'Igualada de l'Arxiu Comarcal d'Igualada. Inventaris dels fons musicals de Catalunya; 9 (Barcelona: $\mathrm{UAB}, 2016)$ : 521 pages.

All these volumes include an extended introductory study of the main features of the collection, its history, and any information than may help to complete the biography of the composers represented ${ }^{12}$.

12. For more information, see the Web site of the UAB Publications Service: http://publicacions.uab.cat /llibres/titols_llibres.asp?TITOL=inventaris+dels+fons+musicals+de+catalunya\&Submit3=Cercar, accessed 18 August 2017. 


\section{The Website: IFMuC Digital Database and the Wiki Project}

On 3 December 2015, the IFMuC Web site (http://ifmuc.uab.cat [accessed 18 August 2017]) was officially presented at the Escola Superior de Música de Catalunya ('Higher School of Music of Catalonia'). This Web site contains useful online tools related to the unearthing of Catalan musical heritage, such as a highly detailed census of the Catalan music collection (titled Cens Fontes Musicae Cataloniae), the introductions to the published inventories and, above all, a digital database that enables immediate access to more than 10,000 records $^{13}$.

This digital database undoubtedly constitutes the greatest milestone hitherto of the IFMuC Project. For several years, in the context of the management of European musical heritage, there has been an increasing interest in the creation of digital databases in order to provide access to descriptive information about the collections of musical manuscripts conserved in archives and libraries. Aware of this, the IFMuC Project has created an engaging digital platform to allow the international community to access the entirety of the catalogued records.

This digital database, not designed to substitute for the print edition of the inventories, makes it easier to locate material, allowing searches by title (generic), author, summary, or keyword. The digital records contain the same information as the manual and print ones, including the digital image of the musical incipit. Such a systematic and uniform structure facilitates interconnected data searches in different archives and collections. Moreover, this structure is designed to be adaptable to other database cataloguing rules, such as RISM or CEDOC. The next step, and one which we hope to accomplish in the future, is to include, in the same database, the entire digitalised music materials.

On the IFMuC Web site, there is another tool that relates directly to the digital database: the IFMuC Wiki Project. Leveraging the possibilities of open-access digital wiki platforms, the IFMuC Wiki Project offers the corresponding entries on Viquipèdia (https://ca.wikipedia.org/wiki/Portada [accessed 18 August 2017]) - the Catalan Wikipedia-for musicians that appear in the inventories. This work is mainly being done by students pursuing a degree in musicology, who have to prepare the bio-bibliographical information about previously unpublished Catalan composers in order to create new Wikipedia articles based on historical documentation sources and the musical repertory registered in the IFMuC inventories. Another task performed by the students is the revision and updating of existing articles on Catalan composers and subjects related to Catalan musical heritage.

\section{Editing the Repertory: The 'Mestres Catalans Antics. Quaderns dels Fons Musicals de Cata- lunya' Series}

The 'Mestres Catalans Antics. Quaderns dels Fons Musicals de Catalunya' (Early Catalan Masters. Booklets of the Musical Collections of Catalonia) series aims to disseminate the most representative works of Catalan musical heritage, as discovered by the IFMuC Project, through the publication of transcriptions along with pertinent introductory studies in Catalan, Spanish, and English.

The purpose of this series is to recover the documented musical heritage of Catalonia in the form of printed scores, thereby providing a new channel for the dissemination of

13. For more information, see Josep Maria Gregori i Cifré, "El nou web IFMuC al servei del patrimoni musical de Catalunya: <http://ifmuc.uab.cat>, in Revista Catalana de Musicologia 8 (2015): 23-35. 
the compositional repertory of early Catalan composers. When we launched the IFMuC Project and discovered the heritage value of these archives, we thought that a good way to start recovering the compositional repertoire of the old masters was to involve the institutions themselves. This was achieved through their participation in a periodical copublication devoted to disseminating musical items in their respective archives. Such enthusiasm was aroused by this initiative, that it has finally been possible to bring to light the vast treasury of sound that was overlooked in the archives, so that it can be performed and incorporated in new programmes of concerts and performances. This project, directed by Josep Maria Gregori i Cifré and Bernat Cabré i Cercós, has involved the collaboration of the UAB Chair of Music Heritage, Tritó (Amalgama) and Ficta editions, the Catalan Musicological Society (affiliated with the Institute of Catalan Studies), and many other institutions-dioceses, local and regional councils and archives-that are responsible in some way for the catalogued archives, and with the endorsement of the Department of Culture of the Autonomous Government of Catalonia.

Between 2013 and 2016, eight booklets were published:

1) Tomàs Milans i Godayol. Cantates $i$ "tonos" per a 1 i 2 veus amb instruments, transc. Josep Dolcet and Jordi Ribell (Barcelona: Amalgama, 2013; from the parish archive of Sant Pere and Sant Pau de Canet de Mar).

2) Tomàs Milans i Godayol. "Aquel buen pastor", sarsuela per a 3 veus $i$ instruments, transc. Jordi Ribell (Barcelona: Amalgama, 2013; from the parish archive of Sant Pere i Sant Pau de Canet de Mar).

3) Carles Baguer. Contradanses, minuets i passapies per a orquestra, transc. Carme Monells and Xavier Pallàs (Barcelona: Amalgama, 2014; from the parish church of Sant Esteve d'Olot).

4) Joan Crisòstom Ripollès. Música eclesiàstica per a 1, 2, 4, 6 i 8 veus, transc. Josep Maria Gregori (Barcelona: Amalgama, 2014; from the musical collection of Tarragona Cathedral).

5) La música en el traspàs de Sant Josep Oriol, with two works: Tomàs Milans i Godayol. Lletania de la Mare de Déu per a 4 veus i acompanyament, transc. Josep Maria Gregori; and Felip Olivelles. Stabat Mater per a 4 veus $i$ per a 8 veus amb instruments, transc. by Josep Dolcet (Barcelona: Amalgama, 2014).

6) Tomàs Milans i Godayol. Música eclesiàstica per a 1, 2, 3, 4, 6 i 8 veus, transc. Josep Maria Gregori, Josep Dolcet and Pere Lluís Biosca (Barcelona: Amalgama, 2014).

7) Música eclesiàstica per a 4, 7 i 8 veus, transc. Josep Maria Gregori and Bernat Cabré, with works by Joan Pujol, Marcià Albareda, Josep Reig and Miquel Rosquelles (Barcelona: Ficta, 2015; from the collection of the parish church of Sant Pere i Sant Pau de Canet de Mar).

8) Himnes, motets $i$ responsoris del manuscrit 59 (with works by Joan Pujol, Pere Egidi Fontseca, Pere Riquet, Pere Beuló, Joan Borgueres), transc. Bernat Cabré (Barcelona: Ficta, 2016).

Some of these works have already become part of the current repertoire of musical groups such as La Capella de Música de Santa Maria del Pi (The Music Chapel of Santa Maria del Pi) and La Companyia Musical ${ }^{14}$, which are currently recording and producing two CDs with pieces from the fourth, fifth, and eighth booklets ${ }^{15}$.

These publications are, therefore, only small examples of the richness stored in Catalan music collections and, hence, of the vast quantity of work that must still be done. A constant throughout the history of music in Catalonia has been its capacity to integrate the

14. For more information, see the respective Web sites: http://www.capelladelpi.cat/ and http:// companyiamusical.blogspot.com.es/, both accessed 18 August 2017.

15. Together with InSitu and Ficta Productions, respectively. 
most innovative trends of European music. In fact, Catalonia and Valencia were historically the first gateways for the entry in the Iberian Peninsula of musical innovations from Europe. An excellent example is Tomàs Milans (1672-1742), the hitherto most represented composer in the series and one of the leading figures in the world of Catalan baroque music. Milans held two of the most important musical positions in Catalonia: chapel master of the Palau de la Comtessa (Palace of the Countess), one of the main religious musical institutions in Barcelona, between 1701 and 1714, and afterwards of Girona Cathedral (from 1714 to 1733). Milans' music is an excellent example of the aesthetic changes experienced in Barcelona and Catalonia in the early-eighteenth century, due to the presence in the city of the royal court of Charles of Austria and Elisabeth Christine of Brunswick-Wolfenbuittel between 1705 and 1711 because of the War of Spanish Succession. The existence of foreign musicians, from Vienna and Naples in particular, strongly influenced the musical practices of Catalan composers, as Milans' works demonstrate in some aspects: for example, a change in instrumental treatment, the integration of operatic forms such as recitative and aria da capo, and the evolution of indigenous forms, such as the villancico or the tono, towards the cantata.

\section{Informative Articles in the Revista Musical Catalana}

Similar to the publishing initiatives by its predecessors Maria Ester-Sala and Josep Maria Vilar, the IFMuC Project recently began a series of articles in the Revista Musical Catalana (Catalan Musical Magazine). This veteran magazine belongs to the Consortium of the Palau de la Música Catalana and has become the most important Catalan magazine about music, keeping the general reader in constant touch with the Catalan musical scene, covering both activities in Catalonia and the careers of Catalan musicians on an international level. This initiative is the fruit of an agreement between the IFMuC and the CEDOC, the documentation centre of the Palau de la Música Catalana.

The first collaboration was an article about the music collection of the Cathedral Basilica of Sant Esperit of Terrasa (TerC), in issue 353 (October-November 2016). The aim is to include, in each issue of the magazine, an article about one Catalan music collection, with a report about the composers, repertory, and history. This is an excellent platform for disseminating the results of IFMuC research to a large section of the population, beyond musicologists and musicians, and embracing music lovers and interested readers.

\section{Conclusion: Achievements and Benefits}

The IFMuC's expectations were met by the immense musical richness generated in the past, and that had been conserved in archives, museums, libraries and music documentation centres, being systematically returned to today's society. The project has generated benefits in several different areas:

- Scientific: through the promotion by the national and international scientific community of new research studies (masters projects and Ph.D. theses) on authors, repertories, styles, and epochs from the history of Catalan music that were unknown until now.

- Artistic: through access by national and international performers to catalogue records of these repertories and materials that were unknown until now and the free access that they will have to digitalised manuscripts in the future. 
- Social: all of the national and international society will benefit from the dissemination of these repertories by musical performers and managers through their concert schedules and sound recordings.

- Educational: the teaching of music history will be able to include in its curricula the discovery of repertoires that were unknown until now.

After twelve academic years, in the light of recently published results, the IFMuC Project has done this work with enthusiasm and with the will to serve not just the region, but also the international scientific and artistic community. Simultaneously, these results clearly reveal the need to continue unearthing this rich and fruitful heritage.

\section{APPENDIX \\ Collections in the Cataloguing Process}

- Badalona (Municipal Museum)

- Francesc Argemí Collection

- Barcelona

- Basilica of Santa Maria del Pi

- Parish Church of Sant Vicenç de Sarrià

- Bernat Calbó Puig Collection (Provincial Archive of the Capuchins)

- Robert de la Riba Collection (Provincial Archive of the Capuchins)

- Carme Piñol Collection (Episcopal Public Library of the Seminary)

- Basilica of the Mare de Déu de la Mercè (Episcopal Public Library of the Seminary)

- Collection of the Seminary (Episcopal Public Library of the Seminary)

- Manuscript music collection of the Orfeó Català (Documentation Centre of the Orfeó Català)

- Canet de Mar

- Josep Soler Collection (Parish Archive)

- Cornudella de Montsant

- Parish Church of Santa Maria

- Girona (ADG)

- Girona Cathedral (GiC)

- Church of Sant Feliu of Girona

- Church of Santa Maria de Vilabertran

- Santuari dels Arcs Collection

- Lleida

- Lleida Cathedral (LleC)

- Papiol, El

- Miquel Pongiluppi Collection

- Reus

- Priory Church of Sant Pere

- Ripoll (ACRI)

- Parish Church of Sant Pere 
- Sant Cebrià de Vallalta (CESC)

- Josep Cumellas i Ribó Collection

- Solsona

- Cathedral's collection (ADS)

- Tarragona (AHAT)

- La Selva del Camp Collection

- Salvador Ritort Collection

- Enric Juncosa Collection

- Joaquim Rial Collection

- Joan Grifoll Collection

\section{English Abstract}

Until recently, Catalonia was one of the few European regions still unaware of the richness of its musical heritage in terms of the repertory of compositions by its chapel masters, organists, and musicians, which are conserved but forgotten in numerous, mainly ecclesiastic, archives. At the beginning of the 2001-2002 academic year, at the Department of Art and Musicology of the Universitat Autònoma de Barcelona, a group of researchers and students, undertook a new line of research with the priority of working to recover collections of manuscripts that constitute the musical heritage of Catalonia. This project is ongoing, and now known as the IFMuC Project, the acronym of Inventaris dels Fons Musicals de Catalunya (Inventories of the Catalan Musical Collections).

This article presents the IFMuC Project in an international forum in order to make it known beyond Catalan boundaries. To date, the IFMuC Project has registered almost 300 collections of music manuscripts; seventeen of them now catalogued, with an index of approximately 1,000 composers and 10,358 works, including manuscripts and printed materials. A considerable number of musical collections are still in the cataloguing process. The dissemination process has been conducted through different strategies, including the publishing of printed copies of some series, articles in journals, and in the creation of a Web site (http://ifmuc.uab.cat), an open-access digital database, undoubtedly the greatest milestone hitherto of the IFMuC Project.

\section{French Abstract}

Jusqu'à récemment, la Catalogne était l'une des rares régions en Europe encore ignorante de la richesse de son héritage musical en termes de répertoire de compositions de maitres de chapelle, organistes et musiciens. Bien que tombés dans l'oubli pendant longtemps, ces documents représentent un nombre important d'archives, ecclésiastiques pour la plupart.

Au début de l'année universitaire 2001-2002, au département d'Art et musicologie de l'Université de Barcelone, un groupe de chercheurs ont initié une nouvelle ligne de recherche, avec pour objectif de redécouvrir ces collections de manuscrits. Ce projet se poursuit aujourd'hui et est connu sous le nom IFMuC Project, acronyme de Inventaris dels Fons Musicals de Catalunya (inventaire des collections muciales catalanes).

Cet article présente le projet IFMuC au sein d'un forum international dans le but de le faire connaitre au-delà des frontières catalanes. A ce jour, ce projet comprend presque 300 collections de manuscrits, dont 17 d'entre elles sont déjà cataloguées, avec un index d'environ 1000 compositeurs et 10358 oeuvres, dont des manuscrits et des partitions imprimées.

Un nombre important de collections musicales sont toujours en train d'être cataloguées. Le processus de diffusion a été mené en suivant différentes stratégies de publication de copies imprimées pour certaines séries, articles de journaux, ainsi que la création d'un site internet (http:// ifmuc.nat.cat), une base de données numérique en open-access: sans aucun doute une étape importante jusqu'ici pour le projet IFMuC. 


\section{German Abstract}

Bis vor Kurzem war Katalonien eine der wenigen europäischen Regionen, die den Reichtum ihres musikalischen Erbes - insbesondere in Bezug auf das Repertoire von Kirchenmeistern, Organisten und Instrumentalisten - zwar in zahllosen, überwiegend kirchlichen Archiven wohl bewahrte, aber kaum beachtete. Mit Beginn des akademischen Jahres 2001-2002 nahm eine Gruppe aus Forschenden und Studierenden in der Abteilung für Kunst und Musikwissenschaft der Autonomen Universität Barcelona ein neues Forschungsprojekt auf, bei dem der Schwerpunkt auf der Wiederentdeckung der Musiksammlungen lag, die das musikalische Erbe Kataloniens darstellen. Das inzwischen unter dem Namen IFMuC (Inventaris dels Fons Musicals de Catalunya) bekannte Projekt ist noch nicht abgeschlossen.

Dieser Artikel präsentiert das Projekt IFMuC im internationalen Rahmen, um es über die Grenzen Kataloniens hinaus bekannt zu machen. Bis jetzt hat das Projekt fast 300 Sammlungen von Musikhandschriften aufgenommen, von denen bereits siebzehn katalogisiert sind. Daraus resultiert ein Verzeichnis von 10.358 Werken von etwa 1.000 Komponisten, in dem sowohl Handschriften als auch Drucke aufgeführt sind. Eine nennenswerte Anzahl von Musiksammlungen befindet sich noch im Prozess der Katalogisierung. Das Marketing wird mittels verschiedener Strategien betrieben, beispielsweise durch die Veröffentlichung von Druckausgaben bestimmter Serien, durch Artikel in Zeitschriften sowie über die Einrichtung einer Webseite (http://ifmuc.uab.cat) und einer digitalen Open-Access-Datenbank, zweifellos dem bisher größten Meilenstein des Projektes IFMuC. 